\title{
PENERAPAN MODEL PROBLEM BASED LEARNING TERHADAP KEMAMPUAN PEMECAHAN MASALAH MATEMATIK SISWA SEKOLAH DASAR
}

\author{
Nia Apriani1), Rayi Siti Fitriani2) \\ STKIP Purwakarta \\ Email: niaapriani886@yahoo.com ${ }^{1)}$,rayivee@gmail.com ${ }^{2)}$ \\ Naskah diterima : 6 Maret 2019, direvisi : 19 April 2019, disetujui : 23 April 2019
}

\begin{abstract}
This research starts from the problem of the students' low mathematical problem solving abilities so that it influences learning outcomes under the Minimum Completion Criteria (KKM), namely 6. An alternative solution to improve learning outcomes is by applying a problem based learning model. The method used in this study is a quantitative method with a quasi-experimental type. The design of this study uses Nonequivalent Control group Design. The population taken was all fifth grade students of SDN 2 Nagrikidul. The sample taken is class $5 \mathrm{~A}$ as an experiment and Class $5 \mathrm{~B}$ as a control. The sampling technique used is saturated sampling, where all of these techniques are used as samples in the study. The data collection technique uses objective tests, while the instruments used are tests in the form of essays. The results showed that there was an influence on the ability of mathematical problem solving between the experimental groups by applying the problem based learning model and the control group with the direct intruction model. This is evidenced from the results of the t-test at the $5 \%$ significance level obtained by the calculated significance of $0.939<0.05$. Whereas for the increase, the results of the t-test at the $5 \%$ significance level obtained a calculated significance lower than 0.05 , namely $0.02<0.05$, so that it can be stated that learning with the Problem Based Learning model has an effect on improving mathematical problem solving skills.
\end{abstract}

Keyword: problem based learning, mathematic problem solving

Pengutipan: Hani Handayani. (2019). Penerapan Model Problem Based Learning Terhadap Kemampuan Pemecahan Masalah Matematik Siswa Sekolah Dasar. JMIE: Journal of Madrasah Ibtidaiyah Education,3(1), 2019, 82-90. jmie.v3i1.100.

Permalink/DOI: http://dx.doi.org/ 10.32934/jmie.v3i1.100 


\section{PENDAHULUAN}

Matematika merupakan ilmu universal yang mendasari perkembangan teknologi modern, mempunyai peran dalam berbagai disiplin dan memajukan daya pikir manusia. Lugina (2017, hlm 521) mengemukakan bahwa tidak dapat dipungkiri dalam kehidupan sehari-hari dari tindakan yang mudah sampai yang sulit, matematika tetap dibutuhkan oleh manusia. Sehingga perlu diberikan kepada siswa dari sejak SD untuk membekali kemampuan memecahkan masalah dalam kehidupan sehari-hari.

Menurut Depdiknas (2006) melalui Permendiknas No. 22 tentang Standar Isi telah dinyatakan bahwa tujuan pelajaran matematika di SD/MI salah satunya dalah agar siswa mampu pemecahkan masalah yang meliputi kemampuan memahami masalah, merancang model matematika, menyelesaikan model dan menafsirkan solusi yang diperoleh

Berdasarkan paparan di atas, dicantumkan pula bahwa pemecahkan masalah adalah salah satu tujuan dari pembelajaran matematika. hal ini sesuai dengan National Council Teachers of Mathematics (NCTM) bahwa pembelajaran matematika hendaknya dilakukan dalam upaya untuk mengembangkan kemampuan pemecahan masalah, penalaran dan pembuktian, koneksi matematika, komunikasi matematika, dan representasi Radiyatul \& Hadi (2014, hlm 53).

Kenyataannya dari fakta yang ada bahwa kemampuan pemecahan masalah matematis siswa di Indonesia masih sangat kurang. Ubaidillah (2017, hlm 3) memaparkan bahwa hasil survei yang dilakukan oleh PISA (Programme for International Student Assesment) pada tahun 2009, Indonesia hanya mencapai peringkat 61 dari 65 peserta, ini masih jauh dibawah rata-rata skor internasional yaitu 496 sedangkan Indonesia hanya mencapai rata-rata skor 371.

Kemampuan pemecahan masalah matematis dalam penilaian proses pada PISA adalah kemampuan dalam merumuskan, menggunakan dan menafsirkan matematika untuk memecahkan masalah. Soal-soal matematika dalam studi PISA lebih banyak mengukur kemampuan menalar, pemecahan masalah, berargumentasi dan pemecahan masalah daripada soal-soal yang mengukur kemampuan teknis baku yang berkaitan dengan ingatan dan perhitungan semata. Maka dapat disimpulkan bahwa kemampuan pemecahan masalah matematik siswa Indonesia masih tergolong rendah.

Berdasarkan studi lapangan di salah satu sekolah yang ada di Purwakarta, pada bulan Agustus 2017 lalu. Peneliti menemukan masalah yang berhubungan dengan pemecaham masalah matematika, yaitu ketika dalam proses pembelajaran siswa kurang memahami soal-soal pemecahan masalah matematika. Sehingga tidak sedikit siswa yang mendapatkan nilai dengan hasil belajar di bawah Kriteria Ketuntasan Minimal (KKM).

Hal ini dikarnakan proses pembelajaran masih berpusat kepada guru, siswa tidak terbiasa dihadapkan pada suatu yang nyata sebagai dasar memahami yang abstrak, pembelajaran materi sesuai dengan urutan-urutan yang ada pada buku teks, akibatnya siswa tidak terbiasa berpikir secara kritis, tidak peka terhadap permasalahan yang ditemui dalam kehidupan sehari-hari, serta tidak dapat menyelesaikan permasalahan tersebut. Pada saat proses pembelajaran berlangsung 
aktivitas belajar siswa kurang aktif terlihat dari siswa belum berani mengeluarkan pendapatnya, ketika guru bertanya siswa hanya diam saja, dikarenakan siswa sudah terbiasa dengan mendengarkan apa yang disampaikan oleh guru di depan kelas kemudian mencatat materi pembelajaran yang ada pada buku, hal ini membuktikan bahwa belum terciptanya pembelajaran yang semestinya. Uno (2012, hlm 75) menyatakan suasana yang mestinya tercipta dalam proses pembelajaran adalah bagaimana peserta didik berperan aktif dalam belajar.

Berdasarkan pengertian di atas dapat disimpulkan bahwa masih banyak siswa yang kesulitan dalam memecahan masalah matematika. Herdian (2009, hlm 9) kesulitan yang dialami siswa dalam pembelajaran matematika dikarenakan kurangnya pemahaman dan ketertarikan siswa pada pelajaran matematika. Salah satu faktor penyebabnya adalah pembelajaran yang bersifat abstrak, sehingga siswa hanya sebatas memiliki pengetahuan bukan pada tingkat pemahaman yang mendalam.

Adapun anak SD, umumnya berada pada tahap operasional konkret. Piaget (Ibda, 2015, hlm 34) pada tahap ini anak sudah cukup matang untuk menggunakan pemikiran logika atau operasi, tetapi hanya untuk objek fisik nyata, mereka belum mampu berpikir hanya dengan menggunakan lambang-lambang.

Ketidakmampuan yang dialami siswa dalam menyelesaikan masalah matematika terlihat pada kesalahan dalam proses menyelesaikan sesuai tahapan pemecahan masalah yang dikemukakan oleh Polya (Rahim, 2015, hlm 183), Hal ini akan berpengaruh pada rendahnya kemampuan yang dimiliki siswa dalam matematika, salah satunya adalah kemampuan pemecahan masalah. Selain itu model yang digunakan masih sering dengan menggunakan model konvensional yaitu dengan model direct intruction.

Oleh karenanya, model pembelajaran yang dipandang selaras dan mampu mengembangkan kemampuan pemecahan masalah secara mendalam dapat diterapkan dengan menggunakan model problem based learning. Karena menurut Lestari dan Yudhanegara (2015, hlm 42) mengungkapkan bahwa Problem Based Learning adalah suatu model pembelajaran yang melibatkan siswa untuk menyelesaikan suatu masalah melalui tahap-tahap metode ilmiah sehingga siswa dapat mempelajari pengetahuan yang berhubungan dengan masalah tersebut sekaligus memiliki keterampilan untuk menyelesaikan masalah.

Selanjutnya Lestari dan Yudhanrgara (2015, hlm 43) membagi langkah-langkah Problem Based Learning menjadi 4, yaitu:

1) Orientation (Orientasi siswa terhahap masalah)

Guru menjelaskan tujuan pembelajaran, menjelaskan perangkat yang dibutuhkan, memotivasi siswa, dan mengjukan masalah sebagai langkah awal pembelajaran. Masalah yang diajukan biasanya masalah dalam dunia nyata.

1) Engagement

Siswa terlibat dalam aktivitas penyelesaian masalah

2) Inquiry and investigation

Siswa melakukan penyelidikan dan investigasi dalam rangka menyelesaikan masalah. 


\section{3) Debriefing}

Siswa melakukan tanya jawab dan diskusi terkait kegiatan penyelesaian masalah yang telah dilakukan.

Menurut Branca (Ulvah \& Afriansyah, 2016, hlm 143) kemampuan pemecahan masalah matematik merupakan salah satu tujuan penting dalam pembelajaran matematika bahkan proses pemecahan masalah matematis merupakan jantungnya matematika. Hal di atas diperjelas oleh Mawadah \& Anisah (2015, hlm 167). Kemampuan pemecahan masalah matematika adalah kemampuan megidentifikasi unsur-unsur yang diketahui, ditanyakan, dan kecukupan unsur yang diperlukan, mampu membuat atau menyusun model matematika, dapat memilih dan mengembangkan strategi pemecahan, mampu menjelaskan dan memeriksa kebenaran jawaban yang diperoleh.

Pada penelitian ini indikator kemampuan pemecahan masalah matematis yang digunakan mengacu pada Polya (Nafi'an 2015, hlm 167), yaitu:

1) Memahami masalah (understanding the problem).

Pada aspek memahami masalah melibatkan pendalaman situasi masalah, melakukan pemilahan fakta-fakta, menentukan hubungan diantara fakta-fakta dan membuat formulasi pertanyaan masalah. Setiap masalah yang tertulis, bahkan yang paling mudah sekalipun harus dibaca berulang kali dan informasi yang terdapat dalam masalah dipelajari dengan seksama.

Pada tahap ini siswa harus memahami masalah yang diberikan yaitu menentukan apa yang diketahui, apa yang ditanyakan, apa syaratnya, cukup ataukah berlebihan syarat tersebut untuk menyelesaikan soal yang diberikan.

2) Merencanakan pemecahan masalah (devising a plan).

Rencana solusi dibangun dengan mempertimbangkan struktur masalah dan pertanyaan yang harus dijawab. Dalam proses pembelajaran pemecahan masalah, siswa dikondisikan untuk memiliki pengalaman menerapkan berbagai macam strategi pemecahan masalah. Pada tahap ini siswa harus menunjukkan hubungan antara yang diketahui dan yang ditanyakan, dan menentukan strategi atau cara yang akan digunakan dalam menyelesaikan soal yang diberikan.

3) Melaksanakan rencana pemecahan masalah (carrying out the plan)

Untuk mencari solusi yang tepat, rencana yang sudah dibuat harus dilaksanakan dengan hati-hati. Diagram, tabel atau urutan dibangun secara seksama sehingga si pemecah masalah tidak akan bingung. Jika muncul ketidakkonsistenan ketika melaksanakan rencana, proses harus ditelaah ulang untuk mencari sumber kesulitan masalah.

Pada tahap ini siswa melaksanakan rencana yang telah ditetapkan pada tahap merencanakan pemecahan masalah, dan mengecek setiap langkah yang dilakukan.

4) Memeriksa kembali solusi yang diperoleh (looking back).

Selama melakukan pengecekan, solusi masalah harus dipertimbangkan. Solusi harus tetap cocok terhadap akar masalah meskipun kelihatan tidak beralasan. Pada tahap ini siswa melakukan refleksi yaitu mengecek atau menguji solusi yang telah diperoleh. 


\section{METODOLIGI PENELITIAN}

Metode penelitian ini menggunakan metode kuantitatif dengan jenis kuasi eksperimen. Design penelitian menggunakan Nonequivalent Control group Design. Populasi yang diambil adalah seluruh siswa kelas V SDN 2 Nagrikidul, Adapun dengan sempel yaitu kelas A sebagai kelas eksperimen dan kelas B sebagai kelas kontrol. Teknik sampling digunakan yaitu sampling jenuh. Yang mana teknik sampling ini semua populasi digunakan sebagai sampel dalam penelitian. Instrumen yang digunakan berupa tes dalam bentuk essay. Instrumen ini diberikan pada kelas eksperimen dan kelas kontrol dengan jumlah yang sama yaitu sebanyak 20 butir soal.

Selanjutnya di expertjudgment, yakni dengan mengkonsultasikan instrumen kepada para ahli dalam hal ini dosen pembimbing dan dosen lain yang kompeten. Untuk mengetahui validitas konstruks menggunakan uji coba instrumen dilapangan. Uji coba dilaksanakan di SDN 1 Cilandak. Kemudian dilanjutkan dengan analisis validitas, reliabilitas, tingkat kesukaran, dan daya pembeda setiap butir soal menggunakan bantuan program aplikasi Microsoft Excel.

Berdasarkan hasil uji coba instrument soal, diketahui butir soal yang valid sebanyak 10 butir soal, sedangkan 10 butir soal dinyatakan tidak valid karena indeks validitasnya dibawah $\leq$ 0,381. 10 Soal berikut berarti telah gugur dan tidak dapat digunakan dalam tes penelitian. Selanjutnya hasil coba reliabilitas secara keseluruhan, peneliti memperoleh reliabel 1,04 dengan kriteria sangat tinggi. Maka, dapat disimpulkan bahwa soal tersebut reliabel. Dari butir soal diketahui sebagian soal yang berkategori sedang berjumlah 12 butir soal. Sedangkan soal yang berkategori mudah berjumlah 7 butir soal, sedangkan hasil analisis daya pembeda semua butir soal dikategorikan sangat baik. Sehingga soal yersebut dapat digunakan untuk penelitian.

Setelah data terkumpul kemudian dianalisis dengan menggunakan uji beda, yang mana sebelumnya dilakukan uji prasyarat berupa uji normalitas dan uji homogenitas. Data yang berdistribusi normal dianalisis menggunakan uji $t$, sementara untuk data yang tidak normal dianalisis menggunakan uji non parametrik Mann-Whitney. Penghitungan ini menggunakan bantuan aplikasi SPSS versi 22.

\section{PEMBAHASAN}

Berdasarkan hasil penelitian dapat diketahui bahwa kemampuan awal antara kelas eksperimen dengan kelas kontrol relatif sama.Data tersebut dapat disajikan seperti pada Tabel 1.1

Tabel 1.1

Rata- rata Skor Kemampuan pemecahan masalah

\begin{tabular}{cccc}
\hline \multicolumn{2}{c}{ Pretest } & \multicolumn{2}{c}{ Posttest } \\
\hline Eksperimen & Kontrol & Eksperimen & Kontrol \\
43,83 & 35,90 & 68,31 & 56,55
\end{tabular}

Dari tabel 1.1 dapat dilihat bahwa rata-rata nilai pre-test yang diperoleh kelas eksperimen sebesar 43,83 dan kelas kontrol sebesar 35.90. Sedangkan dari hasil post-test kelas ekeperimen 
sebesar 68,31 dan kelas kontrol sebesar 56,55. Maka dapat disimpulkan bahwa rata-rata post-test kemampuan pemecahan masalah matematik pada kelas eksperimen lebih besar dari rata-rata kelas kontrol.

Tabel 2.2

Hasil uji T Post-test

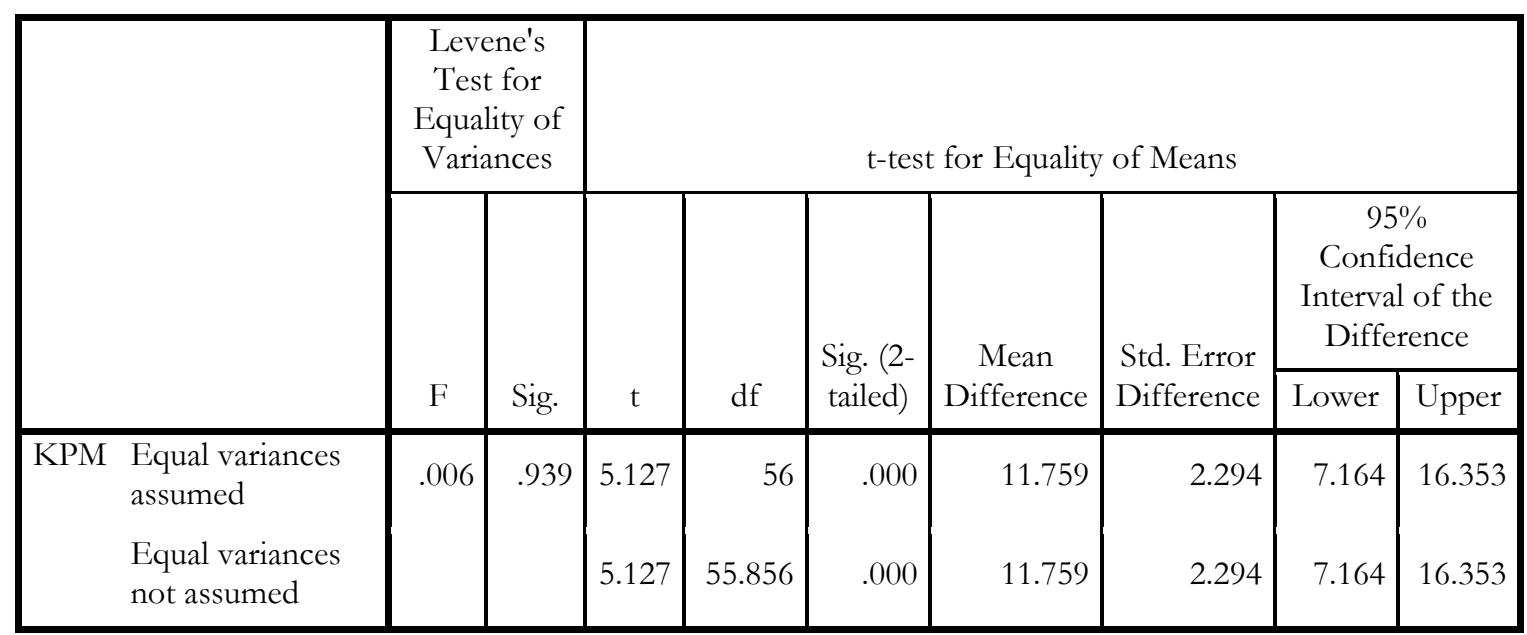

Hal ini diperkuat oleh hasil uji perbedaan rata-rata sebesar 0.00. Artinya, kemampuan pemahaman konsep matematika siswa kelas eksperimen dan kelas kontrol memiliki perbedaan yang signifikan, maka dapat dinyatakan bahwa $\mathrm{H}_{1}$ diterima dan $\mathrm{H}_{0}$ ditolak. Yang artinya ada pengaruh yang signifikan dari hasil posttest kelompok eksperimen dan kelompok kontrol.

Tabel 1.3

Hasil Uji T N-Gain

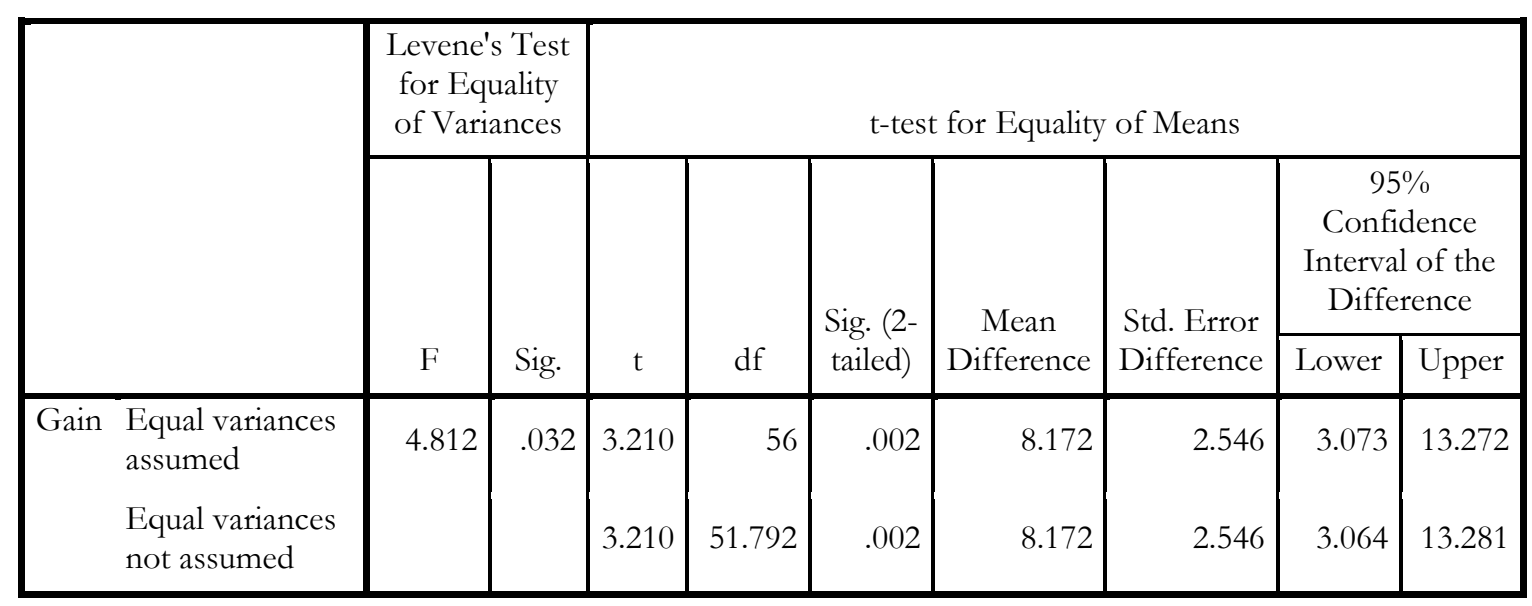

Adapun untuk melihat seberapa besar pengaruh dapat dilihat dari hasil analisis uji hipotesis dengan uji-t independent samples test diperoleh t 4,812. Pada taraf signifikansi 5\% 
diperoleh signifikasi hitung lebih rendah dari 0,05 yaitu 0,02<0,05, sehingga dapat dinyatakan bahwa perbedaan yang ada adalah signifikan. Maka dapat disimpulkan bahwa ada pengaruh yang signifikan model problem based learning terhadap kemampuan pemecahan masalah matematik siswa sekolah dasar karena nilai signifikansi lebih kecil dari 0,05.

Hasil penelitian menunjukan bahwa kemampuan pemecahan masalah matematis dengan model Problem Based Learning terdapat pengaruh dan dapat meningkatkan hasil nilai siswa. Hal ini karena model problem based learning menghadapkan siswa pada suatu masalah sehingga siswa dapat mengembangkan kemampuan berpikir tingkat tinggi daan keterampilan penyelesaian masalah serta memperoleh pengetahuan baru terkait dengan permasalahan tersebut.

Hal di atas sependapat dengan Lestari dan Yudhanegara (2015, hlm 42) yang mengemukakan bahwa Problem Based Learning adalah suatu model pembelajaran yang melibatkan siswa untuk menyelesaika suatu masalah melalui tahap-tahap metode ilmiah sehingga siswa dapat mempelajari pengetahuan yang berhubungan dengan masalah tersebut sekaligus memiliki keterampilan untuk meyelesaikan masalah.

Perbedaan yang didapatkan dari kelas eksperimen dan kelas kontrol yaitu fokus pada indikator kemampuan pemecahan masalah yang mengacu kepada Polya (Nafian 2015, hlm 167) yaitu: memahami masalah, merencanakan penyelesaian, melaksanakan rencana penyelesaian, serta memeriksa proses dan hasil.

Dalam hal ini kelas eksperimen cenderung lebih aktif dan menguasi dalam setiap tahapannya karena mereka sudah terbiasa belajar secara menantang dan berkelompok, selain itu mereka selalu diberikan masalah yang harus diselesaikan berdasarkan instruksi-instruksi yang telah disediakan dalam bahan ajar. Wulandari (2015, hlm 13) menyatakan bahwa model problem based learning adalah suatu model yang menantang siswa untuk belajar bagaimana belajar, bekerja secara berkelompok untuk mencari solusi dari permasalahan dunia nyata.

Hal itu membuat siswa dapat mengingat pembelajaran dengan baik dan menerapkan proses pemecahan masalah secara mandiri. Hal ini sejalan dengan Riyanto (2010,hlm 228) bahwa dalam pembelajaran model Problem Based Learning, siswa dapat belajar, mengingat, dan menerapkan proses belajar secara mandiri.

Berbeda dengan kelas kontrol, mereka cenderung masih berpusat kepada guru. Hal di atas sejalan dengan Zubaidah (2010, hlm 26) bahwa Direct Instruction adalah strategi yang kadar pembelajarannya berpusat pada guru lebih tinggi dan paling sering digunakan oleh para pendidik. Strategi yang melengkapi model pembelajaran ini termasuk di dalamnya metodemetode ceramah, pertayaan didaktik, pengajaran eksplisit, praktek dan latihan serta demonstrasi.

Kardi \& Nur (2000, hlm 8) menyebutkan bahwa Direct Instruction memiliki 5 fase proses pembelajaran yaitu menyampaikan tujuan dan mempesiapkan siswa, menjelaskan pengetahuan dan keterampilan, membimbing pelatihan, mengecek pemahaman dan memberikan umpan balik, dan memberi kesempatan untuk pelatihan dan penerapan.

\section{Simpulan}


Berdasarkan hasil dan pembahasan penelitian, penggunaan model Problem Based Learning memberikan pengaruh positif terhadap kemampuan pemecahan masalah matematik siswa kelas V SD Negeri 2 Nagrikidul tahun ajaran 2017/2018. Hasil analisis uji t menunjukan bahwa nilai signifikan 0,939. Hasil tersebut lebih besar dari 0,05, maka dapat dinyatakan bahwa $\mathrm{H}_{1}$ diterima dan $\mathrm{H}_{0}$ ditolak. Yang artinya ada pengaruh yang signifikan dari hasil posttest kelompok eksperimen dan kelompok kontrol.

Besar pengaruh model Problem Based Learning dapat dilihat dari hasil t-test pada taraf signifikansi 5\% diperoleh signifikasi hitung lebih rendah dari 0,05 yaitu 0,02<0,05, sehingga dapat dinyatakan bahwa perbedaan yang ada adalah signifikan. Maka dapat disimpulkan bahwa pembelajaran dengan model Problem Based Learning dapat meningkatkan kemampuan pemecahan masalah matematik siswa sekolah dasar.

\section{Implikasi}

Berdasarkan penelitian, peneliti menemukan kekurangan yaitu siswa tidak memiliki kepercayaan bahwa masalah yang dipelajari sulit untuk dipecahkan, sehingga siswa merasa enggan untuk mencoba serta membutuhkan waktu yang lama untuk persiapan. Adapun kelebihannya yaitu mampu meningkatkan aktivitas pembelajaran siswa dalam suasana menyenangkan, mengembangkan kemampuan siswa untuk berpikir kritis, mengaplikasikan pengetahuan yang mereka miliki dalam dunia nyata, dan mengarahkan siswa menjadi pembelajar yang mandiri.

\section{Rekomendasi}

Model Problem Based Learning ini diharapkan dapat digunakan oleh pembaca dan peneliti selanjutnya dalam proses pembelajaran untuk materi yang berbeda dan kelas yang berbeda.

\section{DAFTAR PUSTAKA}

Depdiknas (2006) “Kurikulum Tingkat Satuan Pendidikan”. Jakarta: Balitbang Depdiknas.

Ibda, F. (2015). "Perkembangan Kognitif: Teori Jean Piaget”. Intelektualita. Volume 3 No 1.

Kardi, S dan Nur, M. (2000). “Pengajaran Langsung”. Surabaya: University.

Lestari, K.A, \& Yudhanrgara, M. R. (2015. Penelitian pendidikan matematika. Bandung: Refika Aditama.

Lugina, R. D. (2017). “Upaya Meningkatkan Hasil Belajar Matematika Materi KPK dan FPB Melalui Model Quantum Teaching”. e-jurnalmitrapendidikan. Volume 1. No. 5.

Mawaddah, S. \& Anisah, H. (2015). "Kemampuan Pemecahan Masalah Matematis Siswa Pada Pembelajaran Matematika Dengan Menggunakan Model Pembelajaran Generatif (Generative Learning) Di Smp". Edu-Mat Jurnal Pendidikan Matematika. Volume 3 Nomor 2. $\mathrm{H} \operatorname{lm} 166-175$. 
Nafi'an, M. I (2014). "Kemampuan Siswa Dalam Menyelesaikan Soal Cerita Ditinjau Dari Gender Di Sekolah Dasar”. Prosiding ISBN: 978 - 97916353 - 6 - 3. Yogyakarta: Universitas Negeri Yogyakarta.

Radiyatul \& Hadi, S (2014) "Metode Pemecahan Masalah Menurut Polya Untuk Mengembangkan Kemampuan Siswa Dalam Pemecahan Masalah Matematis Di Sekolah Menengah Pertama". Edu-Mat Jurnal Pendidikan Matematika. Volume 2, Nomor 1, hlm 53 -61 .

Rahim, A. (2015). “Eksplorasi Kesulitan dalam Menyelesaikan Soal Cerita yang Berkaitan dengan Kelipatan Persekutuan Terkecil dan Faktor Persekutuan Terbesar Ditinjau Dari Perbedaan Gender". Prosiding Seminar Nasional ISSN 2443-1109. Volume 02 No. 1 hal 183-184.

Riyanto, Y. (2010). Paradigma Pembelajaran sebagai Referensi bagi Pendidik dalam Implementasi Pembelajaran yang Efektif dan Berkualitas. Jakrta: Prenada Media Group.

Ubaidillah, Z. (2017) "Pengaruh Model Problem Based Learning Terhadap Kemampuan Pemecahan Masalah Matematis Siswa”. Skripsi. Jakarta: Universitas Islam Negeri Syarif Hidayatullah.

Ulvah, S \& Afriansyah, A. E (2016) "Kemampuan Pemecahan Masalah Matematis Siswa Ditinjau Melalui Model Pembelajaran SAVI Dan Konvensional”. Jumal Riset Pendidikan. Vol. 2, No. 2, ISSN: 2460-1470 142.

Uno, H \& Koni, S. (2012) “Assessment Pembelajaran”. Jakarta: Bumi Aksara.

Wulandari, T. E. (2015). Pengaruh Penerapan Problem Based Learning Terhadap Kemandirian Belajar IPA Siswa Kelas IV SD Se-Gugus III Kecamatan Temon Kabupaten Kulon Progo. Skripsi. Yogyakarta: Universitas Negeri Yogyakarta.

Zubaidah, S. (2010). Restrukturisasi Pemahaman Berbagai Istilah Pada Penulisan Komponen Metode Dalam Rencana Pelaksanaan Pembelajaran, (online), (http://teqip.com/download/jteqip/jurnal- 20-37.pdf, diakses 10 Mei 2018). 